\title{
Quality management in Human Milk Banks: a scope review
}

\author{
Gestão da qualidade em Banco de Leite Humano: revisão de escopo \\ Gestión de la calidad en los Bancos de Leche Humana: revisión de alcance
}

Rosana Rodrigues Figueira Fogliano' ORCID: 0000-0003-4129-4933

Elena Bohomol ORCID: 0000-0002-7196-0266

Mariana Cabral Schveitzer ORCID: 0000-0001-9833-2932

Kelly Pereira Coca ORCID: 0000-0002-3604-852X

Ana Cristina Freitas de Vilhena Abrão ORCID: 0000-0001-6249-2467

'Universidade Federal de São Paulo, São Paulo, São Paulo, Brazil.

How to cite this article:

Fogliano RRF, Bohomol E, Schveitzer MC, Coca KP, Abrão ACFV. Quality management in Human Milk Banks: a scope review. Rev Bras Enferm. 2020;73(Suppl 6):e20190640. doi: http://dx.doi.org/10.1590/0034-7167-2019-0640

Corresponding author: Rosana Rodrigues Figueira Fogliano Email: rosana.fogliano@unifesp.br

EDITOR IN CHIEF: Dulce Barbosa ASSOCIATE EDITOR: Ana Fátima Fernandes

Submission: 12-06-2019

Approval: 05-24-2020

\begin{abstract}
Objectives: to identify the main quality management interventions used by professionals working at Human Milk Banks. Methods: a scope review conducted at PubMed, VHL, Scopus, SCiELO, CAPES thesis and Google Scholar databases. Primary studies were included that address quality improvement strategies to improve Milk Bank processes in Portuguese, English and Spanish. Results: search totaled 192 scientific studies, 17 of which met the objective of the study and inclusion criteria. The main quality management interventions used in the Human Milk Bank addressed tools for continuous improvement. Six were aimed at improving processes, one to prevent errors and failures and two to achieve continuous monitoring. Final Considerations: the tools used by professionals working in Human Milk Banks have demonstrated effectiveness in managing the quality of services.

Descriptors: Milk Banks; Quality Management; Health Services Administration; Review; Nursing
\end{abstract}

\section{RESUMO}

Objetivos: identificar as principais intervenções de gestão da qualidade utilizadas pelos profissionais que atuam em Bancos de Leite Humano. Métodos: revisão de escopo realizada nas bases de dados PubMed, BVS, Scopus, SciELO, Banco de teses da CAPES e Google Acadêmico. Foram incluídos estudos primários que abordam as estratégias de melhoria da qualidade para aperfeiçoar os processos nos Bancos de Leite nos idiomas português, inglês e espanhol. Resultados: a busca totalizou 192 produções científicas, sendo que 17 atenderam ao objetivo do estudo e critérios de inclusão. As principais intervenções de gestão da qualidade utilizadas em Bancos de Leite Humano abordaram ferramentas de melhoria contínua, sendo seis voltadas para aperfeiçoar os processos, uma para prevenir erros e falhas e duas para alcançar o monitoramento contínuo. Considerações Finais: as ferramentas usadas pelos profissionais que atuam em Bancos de Leite Humano demonstraram efetividade na gestão da qualidade dos serviços.

Descritores: Bancos de Leite; Gestão da Qualidade; Administração de Serviços de Saúde; Revisão, Enfermagem.

\section{RESUMEN}

Objetivos: identificar las principales intervenciones de gestión de la calidad utilizadas por los profesionales que trabajan en los Bancos de Leche Humana. Métodos: revisión de alcance realizada en las bases de datos de tesis PubMed, BVS, Scopus, SciELO, CAPES y Google Scholar. Se incluyeron estudios primarios que abordan estrategias de mejora de la calidad para mejorar los procesos del Banco de Leche en portugués, inglés y español. Resultados: la búsqueda totalizó 192 producciones científicas, de las cuales 17 cumplieron el objetivo del estudio y los criterios de inclusión. Las principales intervenciones de gestión de la calidad utilizadas en Bancos de Leche Humanas abordaron herramientas para la mejora continua, con seis destinadas a mejorar los procesos, una para evitar errores y fallas y dos para lograr un monitoreo continuo. Consideraciones Finales: las herramientas utilizadas por los profesionales que trabajan en los Bancos de Leche Humana han demostrado su eficacia en la gestión de la calidad de los servicios.

Descriptores: Bancos de Leche; Gestión de la Calidad; Administración de los Servicios de Salud; Revisión; Enfermería. 


\section{INTRODUCTION}

Quality management is a model that enables standardization, security, rationalization and continuous improvement of services. It has proved to be a worldwide trend and a differential for organizations ${ }^{(1)}$. Quality management incorporation in health promotes a systemic approach and involves all managerial functions such as planning, organization, direction and control of the activities developed. These functions allow the manager to review the performance of processes, control costs, improve the meeting of customer needs, and develop employee knowledge ${ }^{(2)}$.

With regard to Human Milk Banks (HMB) in Brazil, quality management has been implemented as a guiding model to guarantee the supply of human milk (HM) with quality and safety in the microbiological, nutritional and operational efficiency of processes ${ }^{(3-5)}$. According to the Brazilian Human Milk Bank network, $\mathrm{HMB}$ are responsible for promoting, supporting and protecting breastfeeding, by providing assistance to mothers and offering HM to premature and hospitalized newborns ${ }^{(5-6)}$. Therefore, standardizing processes ensures the quality of the distributed $H M$, considered the best and safest option in the impossibility of breastfeeding directly on the breast, according to the World Health Organization $(\mathrm{WHO})^{(7)}$, American Academy of Pediatrics ${ }^{(8)}$, and Ministry of Health of Brazil(5).

Studies show the increasing use of expressed human milk (EBM) in the Neonatal Intensive Care Unit (NICU) and as a consequence, there is also the expansion of $\mathrm{HMB}$ in the world. There are currently approximately $500 \mathrm{HMB}$ in more than 37 countries $^{(4)}$. In Brazil, the number of HMB exceeds 200 , which requires standardization of practices and monitoring of the performance of process results to ensure the quality of processed and distributed milk ${ }^{(9)}$. The HMB system in general, consists of processing, $\mathrm{HM}$ quality control and assistance processes ${ }^{(5-6)}$. Considering the specificity of HM, nursing literature is more diverse in the control of physical-chemical, nutritional and microbiological quality. However, there is a lack of knowledge regarding the improvement intervention strategies applied in the activities developed in the HMB in the general scope of the process, from milk capture to its distribution.

In this sense, there is a need to explore the quality management practices implemented. It is essential that quality is based on actions and that allows professionals to monitor the performance of operational procedures, assess the results and continuously review the methods adopted. Expressed milk is destined to serve a vulnerable population that is hospitalized in the NICU of hospitals.

\section{OBJECTIVES}

To identify the main quality management interventions used by professionals working at HMB.

\section{METHODS}

This is a scope review that aims to map scientific studies in a broader and more comprehensive way, to provide more explicit details on each stage of its development, increasing the clarity and rigor of the review and identifying gaps in the knowledge base of the researches ${ }^{(10)}$. The review was developed following the 5 steps: (1) identification of the research question; (2) identification of relevant studies; (3) selection of studies; (4) data extraction; (5) grouping, writing, and synthesis of results ${ }^{(10)}$.

The research question was elaborated from PCC strategy, acronym of $\mathrm{P}$ (Population) related to health professionals who work in $\mathrm{HMB}$; $\mathrm{C}$ (Concept) quality management; and C (Context) related to $\mathrm{HMB}^{(10-11)}$. Therefore, it was elaborated with the following question: how do health professionals carry out quality management in $\mathrm{HMB}$ ?

To identify the relevant studies, searches were conducted at the National Library of Medicine (PubMed), Virtual Health Library (BVS), Scopus; two digital libraries Scientific Eletronic Librany Online (SciELO), dissertation and thesis databases of the Coordination for the Improvement of Higher Education Personnel (Coordenação de Aperfeiçoamento de Pessoal de Nível Superior, abbreviated (APES) of the Ministry of Education of Brazil.

Search was carried out from February to June 2019 using the Health Sciences Descriptors (DeCS) at the BVS, CAPES and SciELO in Portuguese: "Profissional da Saúde", "Banco de Leite Humano", "Gestão da Qualidade", "Indicadores de Qualidade em Assistência à Saúde", "Qualidade da Assistência à Saúde", "Administração de Serviços de Saúde", "Controle de Qualidade". For PubMed and Scopus, Medical Subject Headings (Mesh) terms were used: "Health Personnel”, "Milk Banks", "Quality Management", "Quality Indicator Health Care", "Quality of Health Care", "Health Services Administration", "Quality Control". The descriptors "Banco de Leite Humano" and "Human Milk Banks" were combined in each database using the Boolean operators AND with all other descriptors and in pairs. To expand the search strategy, Google Scholar was included using combinations of the following terms: "Indicators", "Quality Management", "Quality Improvement", "Quality Control" and "Human Milk Banks". EndNote ${ }^{\circ}$ was used to manage references, import articles from databases, and organize them into groups.

For the selection of studies, the inclusion criteria were quantitative or qualitative primary studies and review studies, published in Portuguese, Spanish, and English, without time restrictions. All studies that addressed the quality improvement strategies applied to improve the processes in HMB were included, according to established criteria. The publications were selected and analyzed, from reading titles, abstracts, and full material, by two independent reviewers and the differences were discussed among the researchers. All included studies followed the ethical precepts required.

Data extraction was performed using a form to obtain the following findings: characterization of studies (title, year and country of origin); objective, main results and quality management interventions used by professionals working at HMB. The study selection steps were performed according to the Preferred Reporting Items for Systematic Review and Meta-Analyses (PRISMA) ${ }^{(12)}$.

To classify the strategies found, we used the theoretical framework that guides the principles of total quality management defined by Kaoru Ishikawa ${ }^{(13)}$. Kaoru Ishikawa's management proposal for total quality control represented transformation of the Japanese quality model, and emphasized the monitoring of processes through quality control circle. To that end, he uses a set of tools with specific applications for analysis and problem 
solving that happens, with participation of people involved in the service ${ }^{(13)}$.

\section{RESULTS}

The searches resulted in a total of 192 scientific studies distributed in the databases. Figure 1 shows the stages and the results obtained, which consisted of 15 articles and two dissertations totaling 17 studies.

Chart 1 shows the authors, titles, country, journals and year of publication. When the origin of the studies was analyzed, nine (52.9\%) were carried out in Brazil, three (17.6\%) in the United States of America; two (11.7\%) in Italy; and a publication referring to Australia, South Africa and Poland, respectively. The identified studies were published between 2003 and 2019, with greater interest in the theme in 2014 and 2015 with seven studies, equivalent to $41.2 \%$.

Chart 2 presents the authors, objective of the study, improvement interventions used by professionals working at HMB and the outcomes achieved.

The results demonstrated the use of nine quality tools as interventions to support and improve HMB quality management activities. These activities addressed tools to improvement of processes in $64.7 \%(n=11)$ of the studies, $11.7 \%(n=2)$ to prevent errors and failures and $35.2 \%(n=6)$ to achieve continuous monitoring results. Chart 3 presents an overview of the tools, the processes involved and classification of the studies.

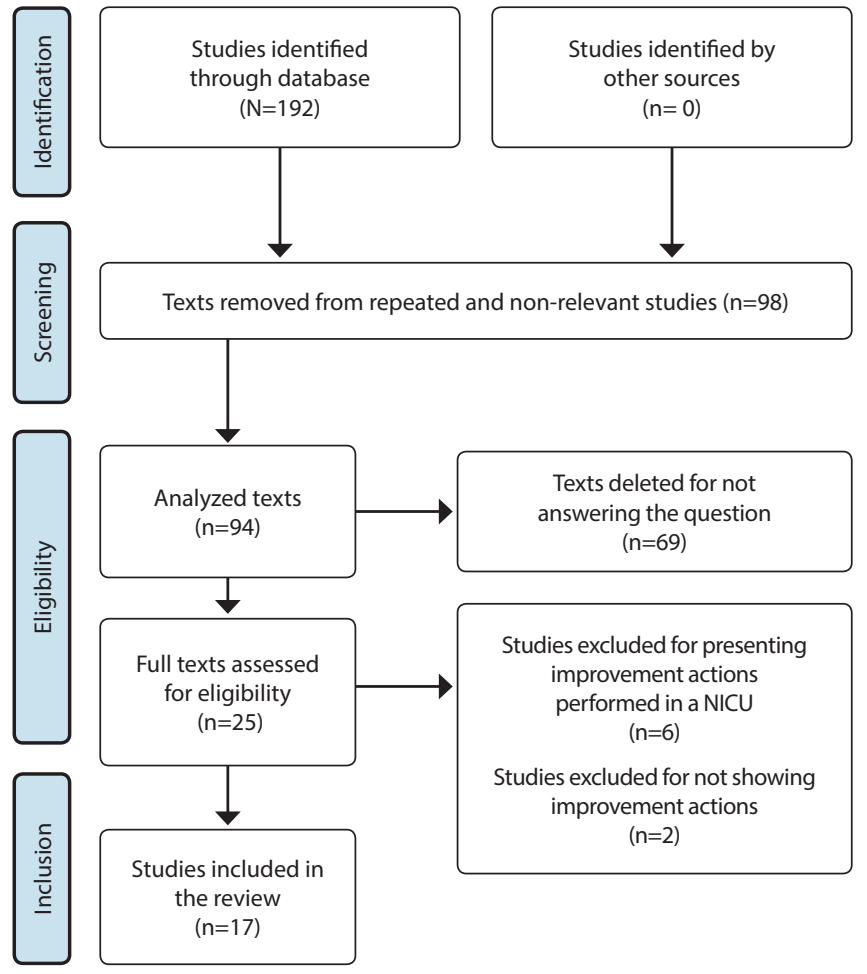

Figure 1 - Flow diagram of the selection of review articles according to PRISMA, São Paulo, São Paulo, Brazil, 2019

Chart 1 - Articles selected in the scope review according to authorship, title, country of study, journal and year of publication, São Paulo, São Paulo, Brazil, 2019

\begin{tabular}{|c|c|c|c|c|}
\hline Authors & Title & Country & Journal & Year \\
\hline $\begin{array}{l}\text { Wesolowska A, Sinkiewicz-Darol } \\
\text { E, Barbarska O, Bernatowicz-Lojko } \\
\text { U, Borszewska-Kornacka MK, van } \\
\text { Goudoever JB }{ }^{(14)}\end{array}$ & $\begin{array}{l}\text { Innovative Techniques of Processing Human Milk to Preserve } \\
\text { Key Components }\end{array}$ & Poland & Nutrients & 2019 \\
\hline Hartmann $\mathrm{BT}^{(15)}$ & $\begin{array}{l}\text { Ensuring Safety in Donor Human Milk Banking in Neonatal } \\
\text { Intensive Care }\end{array}$ & Australia & Clinics in Perinatology & 2017 \\
\hline $\begin{array}{l}\text { Peila C, Emmerik NE, Giribaldi M, } \\
\text { et al. }{ }^{(16)}\end{array}$ & $\begin{array}{l}\text { Human Milk Processing: A Systematic Review of Innovative } \\
\text { Techniques to Ensure the Safety and Quality of Donor Milk }\end{array}$ & Italy & $\begin{array}{l}\text { Journal of Pediatric } \\
\text { Gastroenterology \& } \\
\text { Nutrition }\end{array}$ & 2017 \\
\hline Grazziotin et al. ${ }^{(17)}$ & $\begin{array}{l}\text { Analysis of the Storage Methods for Raw Human Milk from } \\
\text { Mothers with Infants Admitted to a Neonatal Intensive Care } \\
\text { Unit, According to Brazilian Regulations }\end{array}$ & Brazil & $\begin{array}{l}\text { Journal of Human } \\
\text { Lactation }\end{array}$ & 2016 \\
\hline $\begin{array}{l}\text { Naicker M, Coutsoudis A, Israel- } \\
\text { Ballard K, Chaudhri R, Perin N, } \\
\text { Mlisana K. }{ }^{(18)}\end{array}$ & $\begin{array}{l}\text { Demonstrating the efficacy of the FoneAstra pasteurization } \\
\text { monitor for human milk pasteurization in resourcelimited } \\
\text { settings }\end{array}$ & $\begin{array}{l}\text { South } \\
\text { Africa }\end{array}$ & Breastfeeding Medicine & 2015 \\
\hline $\begin{array}{l}\text { De Nisi G, Moro GE, Arslanoglu S, } \\
\text { Ambruzzi AM, Biasini A, Profeti C, } \\
\text { et al. }{ }^{(19)}\end{array}$ & Survey of Italian human milk banks & Italy & $\begin{array}{l}\text { Journal of Human } \\
\text { Lactation }\end{array}$ & 2015 \\
\hline $\begin{array}{l}\text { ME Maes, MT Possamai, MG } \\
\text { Assoler, FAH Sardá }\end{array}$ & Sistema HACCP em banco de leite humano & Brazil & Higiene Alimentar & 2015 \\
\hline $\begin{array}{l}\text { Menezes G, de Lima-Cavalcanti L, } \\
\text { de Morais-Oliveira AM, Costa- } \\
\text { Pinto Rde M, Steffen-Abdallah } \\
\text { VO }^{(21)}\end{array}$ & $\begin{array}{l}\text { Evaluation of home collection performed by a human milk } \\
\text { bank in a university hospital in Brazil }\end{array}$ & Brazil & Salud Publica de Mexico & 2014 \\
\hline $\begin{array}{l}\text { Brownell EA, Lussier MM, Herson } \\
\text { VC, Hagadorn JI, Marinelli KA }{ }^{(22)}\end{array}$ & $\begin{array}{l}\text { Donor human milk bank data collection in north America: an } \\
\text { assessment of current status and future needs }\end{array}$ & $\begin{array}{l}\text { United } \\
\text { States }\end{array}$ & $\begin{array}{l}\text { Journal of Human } \\
\text { Lactation }\end{array}$ & 2014 \\
\hline
\end{tabular}


Chart 1 (concluded)

\begin{tabular}{|c|c|c|c|c|}
\hline Authors & Title & Country & Journal & Year \\
\hline $\begin{array}{l}\text { Spatz, D. L., Schmidt, K. J. \& } \\
\text { Kinzler, S(23) }\end{array}$ & Implementation of a human milk management center & $\begin{array}{l}\text { United } \\
\text { States }\end{array}$ & $\begin{array}{l}\text { Advances in Neonatal } \\
\text { Care }\end{array}$ & 2014 \\
\hline Carroll, $\mathrm{K}^{(24)}$ & $\begin{array}{l}\text { Body dirt or liquid gold? How the 'safety' of donated breastmilk } \\
\text { is constructed for use in neonatal intensive care }\end{array}$ & $\begin{array}{l}\text { United } \\
\text { States }\end{array}$ & Social Studies of Science & 2014 \\
\hline Vieczorek, A., Wolff, L. ${ }^{(25)}$ & $\begin{array}{l}\text { Evaluation of Human Milk Banks in Paraná - Br: a comparative } \\
\text { study }\end{array}$ & Brazil & $\begin{array}{l}\text { Online Brazilian Journal of } \\
\text { Nursing }\end{array}$ & 2012 \\
\hline Torrezan $\mathrm{AC}^{(26)}$ & Gestão do processo assistencial e processos de Banco de leite & Brazil & $\begin{array}{l}\text { Online Master's } \\
\text { Dissertation }\end{array}$ & 2011 \\
\hline $\begin{array}{l}\text { Grazziotin AL, Grazziotin MCB, } \\
\text { Letti LAJ(27) }\end{array}$ & $\begin{array}{l}\text { Disposal of human milk donated to a human milk bank before } \\
\text { and after measures to reduce the amount of milk unsuitable for } \\
\text { consumption }\end{array}$ & Brazil & Jornal de pediatria & 2010 \\
\hline Silva JHF ${ }^{(28)}$ & $\begin{array}{l}\text { Inovações tecnológicas para uma estratégia de qualificação dos } \\
\text { produtos e dos processos de trabalho em Bancos de Leite Humano: } \\
\text { o sistema de gerenciamento BLMWEB }\end{array}$ & Brazil & Master's Dissertation & 2009 \\
\hline $\begin{array}{l}\text { Silva ER, Abdallah VOS, Oliveira } \\
\mathrm{AMM}^{(29)}\end{array}$ & $\begin{array}{l}\text { Qualidade microbiológica do leite humano ordenhado no } \\
\text { domicílio: eficácia de uma educational action }\end{array}$ & Brazil & $\begin{array}{l}5^{\text {th }} \text { Academic Week. } \\
\text { Universidade Federal de } \\
\text { Uberlândia }\end{array}$ & 2008 \\
\hline $\begin{array}{l}\text { Costa ACM, Pereira DCA, Silva JAR, } \\
\text { Neto JPS, Britto MHSS(30) }\end{array}$ & $\begin{array}{l}\text { Avaliação da qualidade dos bancos de leite humano no município } \\
\text { de São Luís- MA, no período de abril a junho de } 2003\end{array}$ & Brazil & $\begin{array}{l}\text { UFMA University Hospital } \\
\text { Journal }\end{array}$ & 2003 \\
\hline
\end{tabular}

Chart 2 - Distribution of selected articles according to authors, year of publication, objectives, improvement interventions and outcome achieved, São Paulo, São Paulo, Brazil, 2019

\begin{tabular}{|c|c|c|c|}
\hline Authors & Objectives & $\begin{array}{l}\text { Improvement } \\
\text { interventions }\end{array}$ & Outcomes \\
\hline $\begin{array}{l}\text { Wesolowska et } \\
\text { al., 2019 }\end{array}$ & $\begin{array}{l}\text { To compare HM pasteurization methods to } \\
\text { improve the safety and quality of donated milk. }\end{array}$ & Critical analysis & $\begin{array}{l}\text { HPP and ultraviolet- } C \text { irradiation methods seem to } \\
\text { minimize losses as a result of HM processing. }\end{array}$ \\
\hline $\begin{array}{l}\text { Hartmann, } \\
2017^{(15)}\end{array}$ & $\begin{array}{l}\text { To assess the risks and benefits for HMB donors } \\
\text { and recipients using a systematic method. }\end{array}$ & $\begin{array}{l}\text { Risk } \\
\text { management - } \\
\text { HACCP }\end{array}$ & $\begin{array}{l}\text { Potential hazards and benefits are identified at each stage } \\
\text { of HMB processes, and the minimum acceptable standard } \\
\text { for safe practice is defined. }\end{array}$ \\
\hline $\begin{array}{l}\text { Peila et al., } \\
2017^{(16)}\end{array}$ & $\begin{array}{l}\text { To assess the evidence on the effectiveness of } \\
\text { new pasteurization techniques on the quality } \\
\text { and safety of HM }\end{array}$ & Critical analysis & $\begin{array}{l}\text { The HTST method showed equivalence to the standard } \\
\text { pasteurization method, guaranteeing the microbiological } \\
\text { safety of HM. }\end{array}$ \\
\hline $\begin{array}{l}\text { Grazziotin et } \\
\text { al., 2016 }\end{array}$ & $\begin{array}{l}\text { To assess the evidence on the raw HM storage } \\
\text { protocol according to Brazilian regulations. }\end{array}$ & Critical analysis & $\begin{array}{l}\text { The methods of storage in refrigeration }\left(5^{\circ} \mathrm{C} / 12 \text { hours }\right) \\
\text { and freezing }\left(20^{\circ} \mathrm{C} / 15 \text { days) were validated and the energy }\right. \\
\text { content of milk was preserved. }\end{array}$ \\
\hline $\begin{array}{l}\text { Naicker et al., } \\
2015^{(18)}\end{array}$ & $\begin{array}{l}\text { To assess the safety and effectiveness of a mobile } \\
\text { pasteurization monitor, FoneAstra, based on } \\
\text { Smartphone, as a quality control system for the } \\
\text { pasteurization process. }\end{array}$ & $\begin{array}{l}\text { Information } \\
\text { technology }\end{array}$ & $\begin{array}{l}\text { None of the samples pasteurized using FoneAstra showed } \\
\text { bacterial growth. The innovative tool proved to be safe, } \\
\text { effective and low cost for HM pasteurization. }\end{array}$ \\
\hline $\begin{array}{l}\text { De Nisi et al., } \\
2015^{(19)}\end{array}$ & $\begin{array}{l}\text { To compare the operating procedures of } 28 \\
\text { Italian HMB to identify areas of strength and } \\
\text { improvement. }\end{array}$ & Benchmarking & $\begin{array}{l}\text { Divergence in the structure (number of hours worked, } \\
\text { number of rooms and number of equipment), in the } \\
\text { selection processes and mandatory microbiological control. }\end{array}$ \\
\hline $\begin{array}{l}\text { ME Maes et al., } \\
2015^{(20)}\end{array}$ & $\begin{array}{l}\text { To manage risk and control food safety hazards } \\
\text { at HMB. }\end{array}$ & $\begin{array}{l}\text { Risk } \\
\text { management - } \\
\text { HACCP }\end{array}$ & $\begin{array}{l}\text { The critical points were identified: } 6 \text { prevented (CCPp), } \\
4 \text { eliminated (CCPe) and } 1 \text { reduced (CCPr), which made } \\
\text { corrective actions possible. }\end{array}$ \\
\hline $\begin{array}{l}\text { Menezes et al., } \\
2014^{(21)}\end{array}$ & $\begin{array}{l}\text { To assess home collection and transport of raw } \\
\text { HM during home visits. }\end{array}$ & Checklist & $\begin{array}{l}\text { Weaknesses in the collection process were identified, such } \\
\text { as hair protection }(93.8 \%) \text {, hand hygiene ( } 83.3 \%) \text {, nail care } \\
(87.5 \%) \text { and neglecting the first drops (33.3\%). }\end{array}$ \\
\hline $\begin{array}{l}\text { Brownell et al., } \\
2014^{(22)}\end{array}$ & $\begin{array}{l}\text { To monitor data from HMBANA belonging to } \\
\text { HMBANA, on the characteristics of the donor } \\
\text { and donated milk, the feasibility and the interest } \\
\text { in participating in a central registry. }\end{array}$ & $\begin{array}{l}\text { Information } \\
\text { technology }\end{array}$ & $\begin{array}{l}\text { There was no uniformity in the data collected. A lack of } \\
\text { standardization and transparency of information was } \\
\text { identified. }\end{array}$ \\
\hline
\end{tabular}


Chart 2 (concluded)

\begin{tabular}{|c|c|c|c|}
\hline Authors & Objectives & $\begin{array}{l}\text { Improvement } \\
\text { interventions }\end{array}$ & Outcomes \\
\hline $\begin{array}{l}\text { Spatz et al., } \\
2014^{(23)}\end{array}$ & $\begin{array}{l}\text { To analyze the key activities in the } \\
\text { implementation of an HM management center } \\
\text { in a children's hospital. }\end{array}$ & Flow mapping & $\begin{array}{l}\text { Structural weaknesses, the need to improve processes, } \\
\text { change in local culture, training of teams and periodic } \\
\text { assessment of results were identified. }\end{array}$ \\
\hline Carroll, 2014 & $\begin{array}{l}\text { To draw the flow of the donated } \mathrm{HM} \text { of two } \mathrm{HMB} \text {, } \\
\text { from selection to distribution and assess the the } \\
\text { process safety. }\end{array}$ & Flow mapping & $\begin{array}{l}\text { The variety of practices and security process in the selection } \\
\text { and education of donors, pasteurization and microbiological } \\
\text { analysis of the HM between the two HMB were identified. }\end{array}$ \\
\hline $\begin{array}{l}\text { Vieczorek \& } \\
\text { Wolff, 2012(25) }\end{array}$ & $\begin{array}{l}\text { To compare the structure and processes of } 8 \\
\text { HMB paranaense based on RDC } 171 / 2006 \text { and } \\
\text { ANVISA's HMB operating manual. }\end{array}$ & Benchmarking & $\begin{array}{l}\text { The weak and strong points in the eight HMB were } \\
\text { identified. The percentage of compliance ranged from } 72 \\
\text { to } 85 \% \text { and non-compliance showed an average of } 21 \% \text {. }\end{array}$ \\
\hline $\begin{array}{l}\text { Torrezan, } \\
2011^{(26)}\end{array}$ & $\begin{array}{l}\text { To implement the Process Management } \\
\text { methodology in HM assistance and processing } \\
\text { activities. }\end{array}$ & $\begin{array}{l}\text { Flow mapping } \\
\text { PDCA } \\
\text { Benchmarking }\end{array}$ & $\begin{array}{l}\text { All stages were known and an action plan to improve and } \\
\text { monitor all processes was implemented. }\end{array}$ \\
\hline $\begin{array}{l}\text { Grazziotin et } \\
\text { al., } 2010^{(27)}\end{array}$ & $\begin{array}{l}\text { To assess the causes of disposal of the donated } \\
\text { HM and the impact of the implemented } \\
\text { measures. }\end{array}$ & Checklist & $\begin{array}{l}\text { The causes of disposal were identified and showed a } \\
\text { positive impact in reducing the volume of discarded } \\
\text { donated milk. }\end{array}$ \\
\hline Silva, $2009^{(28)}$ & $\begin{array}{l}\text { To know the technological innovations produced } \\
\text { by the HMBWEB system in the qualification of } \\
\text { HMB performance. }\end{array}$ & $\begin{array}{l}\text { Information } \\
\text { system }\end{array}$ & $\begin{array}{l}\text { Construction of indicators that qualify HMB management, } \\
\text { processes and procedures. }\end{array}$ \\
\hline $\begin{array}{l}\text { Silva et al., } \\
2008^{(29)}\end{array}$ & $\begin{array}{l}\text { To compare the physical-chemical and } \\
\text { microbiological quality of raw HM at home and at } \\
\text { HMB before and after a new educational action. }\end{array}$ & $\begin{array}{l}\text { Educational } \\
\text { action }\end{array}$ & $\begin{array}{l}\text { There was no improvement in relation to Dornic acidity } \\
\text { and microbiological analysis after educational actions. }\end{array}$ \\
\hline $\begin{array}{l}\text { Costa et al., } \\
2003^{(30)}\end{array}$ & $\begin{array}{l}\text { To compare the structure, processes and results } \\
\text { of two HMB in the city of São Luís, state of } \\
\text { Maranhão. }\end{array}$ & Benchmarking & $\begin{array}{l}\text { Divergences were identified regarding the physical, } \\
\text { organizational and process control structures that } \\
\text { compromise the quality of the product. }\end{array}$ \\
\hline
\end{tabular}

Note: ANVISA - Brazilian National Health Surveillance Agency; HACCP - Hazard Analysis and Critical Control Points; HMB - Human Milk Bank; HMBWEB - Human Milk Bank Management and Production System; HMBANA - Human Milk Banking Association of North America; HoP - Holder Pasteurization; HTST - High-Temperature Short-Time; HPP - High Pressure Processing: HM - Human Milk; CCP - Critical Control Point; PDCA - Plan, Do, Check, Action; DRC - ANVISA's Board Resolution; NICU - Neonatal Intensive Care Unit.

Chart 3 - Human Milk Bank process, studies according to the principles of total quality management, classification of tools and improvements achieved, São Paulo, São Paulo, Brazil, 2019

\begin{tabular}{|l|c|l|}
\hline \multicolumn{1}{|c|}{$\begin{array}{c}\text { Tools/ } \\
\text { Interventions }\end{array}$} & HMB process & Improvements achieved \\
\hline \multirow{2}{*}{ Checklist ${ }^{(21,27)}$} & $\begin{array}{c}\text { Raw HM collection } \\
\text { and transport }\end{array}$ & Improvement of processes \\
\cline { 2 - 3 } & Raw HM selection & Improvement of processes \\
\hline $\begin{array}{l}\text { Educational } \\
\text { action }{ }^{(29)}\end{array}$ & HM collection & Improvement of processes \\
\hline \multirow{2}{*}{ Critical analysis ${ }^{(14,16-17)}$} & Raw HM storage & Improvement of processes \\
\cline { 2 - 3 } Information \\
technology
\end{tabular}

Note: HM - Human Milk; PDCA - Plan, Do, Check, Action; HACCP - Hazard Analysis and Critical Control Points; HMB - Human Milk Banks.

\section{DISCUSSION}

This review allowed us to know the quality management interventions used by professionals working at HMB. Improvement tools were identified aimed at improving processes, risk management, and monitoring results to strengthen the HMB system. Research on implementing quality tools in HMB are little explored.

\section{Tools to improvement of processes}

Among the tools found for the improvement of processes, it is worth highlighting checklist, educational action, critical analysis, new technologies, flow mapping, PDCA cycle. The tools are used to achieve process improvement in $\mathrm{HMB}$ services and contributed to continuously assessing, improving, and monitoring process variability against the standard. Such tools are widely used because they allow the maintenance of good results; improvement of quality standards and process control ${ }^{(13)}$.

Checklist was used in two studies ${ }^{(21,27)}$ to improve the processes of collection, transport and selection of raw $\mathrm{HM}$, and proved to be efficient as a verification script. It allows aligning and standardizing the activities performed by $\mathrm{HMB}$, besides functioning as a reminder for the application of the best evidence ${ }^{(31)}$. Its application has been increasingly common in the health area, and has demonstrated potential to be used as a standardization and communication tool in the Intensive Care Unit, to increase safety and avoid errors ${ }^{(32)}$.

Regarding the educational action applied with donors in the home collection process ${ }^{(29)}$ did not generate evidence of improvement in the identified study, when the parameters of Dornic acidity and microbiological analysis were analyzed. Although intuitive and very common, educational action has had an under-optimal result due to the non-retention of critical 
information by the patient ${ }^{(33)}$. In order to improve this setting, educational action should not be isolated, but associated with other resources that potentiate its action ${ }^{(34-35)}$.

As for critical analysis, used in three studies ${ }^{(14,16-17)}$, it showed the importance of knowing the established scientific evidence and following the quality standards proposed to standardize the management, organization and control of HMB procedures. Critical analysis allowed us to conclude that there are divergences between countries in relation to these protocols and there is a need to implement universal quality principles for all $\mathrm{HMB}$ and neonatal units ${ }^{(36)}$.

Developing innovative and low-cost Information Technologies has also been studied ${ }^{(18)}$ as improvement actions during the pasteurization process and is a reality that should be considered. One of the strategies used by Brazilian HMB was to operate with alternative technologies for the physical, chemical and microbiological quality control of $\mathrm{HM}$, aligning low operating costs and technical rigor, ensuring the quality of the distributed product ${ }^{(6)}$.

The flow mapping used in three studies ${ }^{(23-24,26)}$ and the PDCA cycle implemented in another study ${ }^{(26)}$ also allowed a broader managerial view of all processes involving $\mathrm{HM}$, because it made it possible to detail the sequence of activities, identify deviations or failures that need to be corrected to improve the final performance and security of HMB services. Nursing literature demonstrates the value of PDCA cycle as the most useful tool in implementing of quality programs in health ${ }^{(37)}$. This method is an initial component of the quality process approach; its application requires compliance with all steps, otherwise the varied practice will compromise its effectiveness as a method of improvement ${ }^{(37)}$. The use of these tools for changes in practices proved to be a successful strategy to increase the rates of breast milk use in premature newborns ${ }^{(38-39)}$.

Despite the different purposes mentioned in the studies, all publications converge to the need to seek improvements in the performance of critical areas and demonstrates a challenging and dynamic behavior in relation to management practices that mark the HMB setting. Tool deployments range from the simplest, such as checklist, to the most comprehensive ones, like critical analysis, and present themselves as an opportunity for improvement in the quality domain.

\section{Tools for risk management}

Only the Hazard Analysis and Critical Control Point (HACCP) has been identified for risk management. This process safety strategy is one of the most important axes to offer safe and high-quality $\mathrm{HM}$. This is a prospective assessment carried out in a systemic and continuous way to identify situations that may affect the safety of organizational processes and procedures ${ }^{(40)}$. With increased emphasis on all types of avoidable errors, risk management has been an increasingly common concern addressed by HMB, for identifying failures and hazards during the processing and administration of $\mathrm{LH}^{(40)}$.

HACCP was implemented and two studies ${ }^{(15,20)}$, and it is as a food safety management system that enables the analysis and control of physical hazards, chemical and/or biological products at each step of production ${ }^{(41)}$. In countries that do not have specific legislation to support and control the use of HM, risk management has been implemented as a quality management system to develop the standards of operational procedures ${ }^{(42)}$.

\section{Tools for monitoring results}

For management of the results, two tools, benchmarking and analysis of quality indicators, were found.

Benchmarking was used in four studies ${ }^{(19,25-26,30)}$ as a management tool, to systematically compare the work processes between the $\mathrm{HMB}$, aiming to achieve better results ${ }^{(43)}$. This demonstrates the importance of the role of $\mathrm{HMB}$ managers in performing periodic assessment actions to boost processes. This tool has been shown to be efficient when there is a need to analyze established metrics to improve practices and modify processes to provide more reliable decision making ${ }^{(43)}$. In contrast, a review on the effectiveness of benchmarking to improve quality in specialized hospitals has shown promising effects, however more robust and structured actions are needed for the use of the tool ${ }^{(44)}$.

Monitoring of indicators in information systems was a tool used in HMB services, in two studies ${ }^{(22,28)}$ made it possible to make strategic comparisons, knowledge about critical points in the processes, assisting the manager in deepening the results to create, share knowledge and evidence of the activities. A study conducted with hospital managers ${ }^{(45)}$ demonstrated that information sharing is essential for the application of the indicator system, besides favoring the development of knowledge. The availability of reliable and quality information supports managers to provide better results.

\section{Study limitations}

Among the limitations of this review, it is possible that some studies were lost due to lack of a taxonomy of managerial terms. Moreover, the inclusion of studies published only in English, Portuguese and Spanish may have limited the identification of more studies.

\section{Contributions to the area}

Identifying the quality management interventions used by professionals working at HMB made it possible to know the most used tools in the area. The scarcity of studies demonstrates a need to deepen the discussion, as it represents a promising strategy for improving the quality of the service. Its implementation and frequent use is still a challenge for most HMB managers. We highlight the need to prepare these professionals for the choice of tools that better meet the strategic objectives of each service.

The challenges for future research are to develop knowledge about improvement tools with their proven effectiveness, in addition to the experience and knowledge of managers and professionals who are at the forefront of services on the relevance of continuous quality improvement.

\section{CONCLUSIONS}

Quality management studies in HMB are still scarce. The quality improvement tools identified were related to process 
improvement, risk analysis and results monitoring. Six tools were effective for process management, showing the concern of HMB managers in structuring the sequence of their activities, solving problems efficiently and, mainly, promoting and ensuring the quality of service. The specific tool for risk management showed the prospective action focused on the safety of processes and patients. However, without a culture and responsibility of managers regarding risks, actions become superficial. Finally, two tools assisted in the management of results, demonstrating the importance of using quality indicators for the establishment of standards and comparison over time. Measuring the quality of services has become a priority in health and are important tools to support management decisions, but it is an exercise that must be developed.

\section{REFERENCES}

1. Beitsch LM, Carretta H, McKeever J, Pattnaik A, Gillen S. The quantitative story behind the quality improvement storyboards: a synthesis of quality improvement projects conducted by the multistate learning collaborative. J Public Health Manag Pract [Internet]. 2013 [cited 2017 Nov 28];19(4):330-40. doi: 10.1097/PHH.0b013e3182629054

2. Agência Nacional de Vigilância Sanitária. Anvisa. Assistência Segura: uma reflexão teórica aplicada à prática [Internet]. 2013 [cited 2017 Nov 29]. Available from: http://www.saude.pr.gov.br/arquivos/File/OSEGURANCA_DO_PACIENTE/Modulo_1AssistenciaSegura.pdf

3. Maia PRS, Novak FR, Almeida JA, Silva DA. Bases conceituais para uma estratégia de gestão: o caso da Rede Nacional de Bancos de Leite Humano. Cad Saúde Pública. 2004;20(6):1700-8. doi: 10.1590/S0102-311X2004000600029

4. Moro GE. History of milk banking: from origin to present time. Breastfeed Med. 2018;13:16-7. doi: 10.1089/bfm.2018.29077.gem

5. Agência Nacional de Vigilância Sanitária. Banco de leite humano: funcionamento, prevenção e controle de riscos[Internet]. Brasília: Anvisa. 2008 [cited 2017 Dec 04]. Available from: http://www.redeblh.fiocruz.br/media/blhanv2008.pdf

6. Human Milk Bank Association North America. Guidelines for the Establishment and Operation of a Donor Human Milk Bank. 2013. doi:10.1007/s13312-014-0424-x

7. World Health Organization. WHO recommendations on postnatal care of the mother and newborn [Internet]. 2013 [cited 2018 Feb 13]. Available from: https://apps.who.int/iris/handle/10665/97603

8. American Academy of Pediatrics. Section on Breastfeeding. Policy statement: Breastfeeding and the use of human milk. Pediatrics. 2012;129(3) e827-e841. doi: 10.1542/peds.2011-3552

9. Rede Global de Banco de Leite Humano (rBLH). Relatório de Produção [Internet]. Rio de Janeiro; 2005[cited 2018 Feb 13]. Available from: https://producao.redeblh.icict.fiocruz.br/portal_blh/blh_brasil.php

10. Arksey H, O'Malley L. Scoping studies: towards a methodological framework. Int J Soc Res Meth. 2005;8(1):19-32. doi: $10.1080 / 1364557032000119616$

11. Santos CMC, Pimenta CAM, Nobre MRC. The PICO strategy for the research question construction and evidence search. Rev Latino-Am Enfermagem. 2007;15(3):508-11. doi: 10.1590/S0104-11692007000300023

12. Galvão TF, Pansani TSA. Harrad D. Principais itens para relatar Revisões sistemáticas e Meta-análises: a recomendação PRISMA. Epidemiol Serv Saúde. 2015;24(2):335-42. doi: 10.5123/S1679-49742015000200017

13. Carvalho MM, Paladini EP. Gestão da qualidade: teoria e casos. 2a ed. Rio de Janeiro: 2012. 429 p

14. Wesolowska A, Sinkiewicz-Darol E, Barbarska O, Bernatowicz-Lojko U, Borszewska-Kornacka MK, van Goudoever JB. Innovative techniques of processing human milk to preserve key components. nutrients. 2019;11(5). doi: 10.3390/nu11051169

15. Hartmann BT. Ensuring safety in donor milk banking in neonatal intensive care. Clin Perinatol. 2017;44(1):131-49. doi: 10.1016/j. clp.2016.11.006

16. Peila C, Emmerik NE, Giribaldi M, et al. Human milk processing: a systematic review of innovative techniques to the ensure safety and quality of donor milk. J Pediatr Gastroenterol Nutr. 2016;64(3):353-61. doi: 10.1097/mpg.0000000000001435

17. Grazziotin MCB, Grazziotin AL, Vidal NM, Freira MHS, Silva RPGVC. Analysis of the storage methods for raw human milk from mothers with infants admitted to a neonatal intensive care unit, according to Brazilian Regulations, J Hum Lact. 2016;32(3):446-54. doi: 10.1177/0890334416647710

18. Naicker M, Coutsoudis A, Israel-Ballard K, Chaudhri R, Perin N, Mlisana K. Demonstrating the efficacy of the foneastra pasteurization monitor for human milk pasteurization in resource-limited settings. Breastfeed Med. 2015;10(2):107-12. doi: 10.1089/bfm.2014.0125

19. Nisi G, Moro GE, Arslanoglu S, Ambruzzi AM, Biasini A, Profeti C, et al. Survey of Italian human milk banks. J Hum Lact. 2015;31(2):294-300. doi: 10.1177/0890334415573502

20. Maes ME, Possamai MT, Assoler MG, Sardá FAH. Sistema APPCC em banco de leite humano, Hig Alim [Internet]. 2015 [cited 2017 Marc 03];29:248-9. Available from: https://www.academia.edu/19465644/SISTEMA_APPCC_EM_BANCO_DE_LEITE_HUMANO

21. Menezes G, Lima-Cavalcanti L, Morais-Oliveira AM, Costa-Pinto RM, Steffen-Abdallah VO. Evaluation of home collection performed by a human milk bank in a university hospital in Brazil. Salud Publica Mex[Internet]. 2014 [cited 2017 Marc 03];56(3):245-50. Available from: https://www.researchgate.net/publication/266381549_Evaluation_of_home_collection_performed_by_a_human_milk_bank_in_a_ university_hospital_in_Brazil 
Quality management in Human Milk Banks: a scope review

22. Brownell EA, Lussier MM, Herson VC, Hagadorn Jl, Marinelli KA. Donor human milk bank data collection in North America: an assessment of current status and future needs. J Hum Lact. 2014;30(1):47-53. doi: 10.1177/0890334413508237

23. Spatz DL, Schmidt KJ, Kinzler S. Implementation of a human milk management center. Adv Neonatal Care. 2014;14(4):253-61. doi: 10.1097/ ANC.0000000000000084

24. Carroll, K. Body dirt or liquid gold? how the "safety" of donated breast milk is constructed for use in neonatal intensive care. Soc Stud Sci. 2013;44(3)466-85. doi: 10.1177/0306312714521705

25. Vieczorek A, Wolff L. Evaluation of human milk banks in Paraná - Br: a comparative study. O Braz J Nurs. 2012;11(1). doi: $10.5935 / 1676-4285.20120009$

26. Torrezan AC. Gestão do processo assistencial e de processamento de Banco de Leite Humano com foco na melhoria da qualidade [Dissertação]. Instituição de Ensino: Universidade Federal de São Carlos, São Carlos; 2010[cited 2017 Jun 07]. Available from: https:// repositorio.ufscar.br/handle/ufscar/3224?show=full

27. Grazziotin AL, Grazziotin MCB, Letti LAJ. Disposal of human milk donated to a human milk bank before and after measures to reduce the amount of milk unsuitable for consumption. J Pediatr. 2010;86(4):290-4. doi: 10.2223/JPED.2014

28. Silva JHF. Inovações tecnológicas para uma estratégia de qualificação dos produtos e dos processos de trabalho em Bancos de Leite Humano: o sistema de gerenciamento BLHWEB. [Dissertação] [Internet]. Escola Nacional de Saúde Pública Sergio Arouca da Fundação Oswaldo Cruz, Rio de Janeiro; 2009 [cited 2017 Jun 07]; Available from: https://www.arca.fiocruz.br/handle/icict/2442

29. Silva ER, Abdallah VOS, Oliveira AMM. Qualidade microbiológica do leite humano ordenhado no domicílio: eficácia de uma ação educativa. In 5a Semana Acadêmica Universidade Federal de Uberlândia, [Internet]. 2008 [cited 2017 Jun 01]. Available from https://ss/4799. websiteseguro.com/swge5/seg/cd2008/pdf/sa08-21093.pdf

30. Costa ACM, Pereira DCA, Silva JAR, Silva Neto JP, Britto MHSS. Avaliação da qualidade dos bancos de leite humano no município de São Luis-Ma, no período de abril a junho de 2003. Rev Hosp Univ UFMA [Internet]. 2003 [cited 2017 Jun 01];38. http://www2.ebserh.gov.br/ documents/16424/491465/Revista_HU_Volume_4_3_SET_DEZ_2003.pdf/181a1c18-30e3-4518-9da3-e7359649fced

31. Agência Nacional de Vigilância Sanitária. Implantação do Núcleo de Segurança do Paciente em Serviços de Saúde - Série Segurança do Paciente e Qualidade em Serviços de Saúde/Agência Nacional de Vigilância Sanitária - Brasília: Anvisa, [Internet]. 2016 [cited 2017 Dec 04]. Available from: http://portal.anvisa.gov.br/documents/33852/3507912/Caderno+6+-+Implanta\%C3\%A7\%C3\%A30+do+N\%C3\%BAcleo+de +Seguran\%C3\%A7a+do+Paciente+em+Servi\%C3\%A7os+de+Sa\%C3\%BAde/cb237a40-ffd1-401f-b7fd-7371e495755c

32. Hallam BD, Kuza CC, Rask K, Fleck JC, Heuston MM, Saha D, et al. Perceptions of rounding checklists in the intensive care unit: a qualitative study. BMJ Qual Saf. 2018;27(10):836-43. doi: 10.1136/bmjqs-2017-007218

33. Nicholson Thomas E, Edwards L, McArdle P. Knowledge is Power: a quality improvement project to increase patient understanding of their hospital stay. BMJ Qual Improv Rep. 2017;1;6(1). doi: 10.1136/bmjquality.u207103.w3042

34. Coca KP, Pinto VL, Westphal F, Mania PN, Abrão AC. Bundle of measures to support Intrahospital exclusive breastfeeding: evidence of systematic reviews. Rev Paul Pediatr. 2018;36(2):214-20. doi: 10.1590/1984-0462/;2018;36;2;00002

35. Bagga N, Nadipineni R, Mohamed A, Poddutoor P, Chirla DK. A quality initiative to improve exclusive breast milk feeding in preterm neonates. Int J Pediatr Adolesc Med. 2018;5(4):131-4. doi: 10.1016/j.ijpam.2018.12.003

36. Picaud JC, Buffin R. Human milk-treatment and quality of banked human milk. Clin Perinatol. 2017;44(1):95-119. doi: 10.1016/j. clp.2016.11.003

37. Taylor MJ, McNicholas C, Nicolay C, Darzi A, Bell D, Reed JE. Systematic review of the application of the plan-do-study-act method to improve quality in healthcare. BMJ Qual Saf. 2014;23:290-8. doi: 10.1136/bmjqs-2013-001862

38. Brandstetter S, Mansen K, DeMarchis A, Nguyen Quyhn N, Engmann C, Israel-Ballard K. A decision tree for donor human milk: an example tool to protect, promote, and support breastfeeding. Pediatr. 2018;6:324. doi: 10.3389/fped.2018.00324

39. Alshaikh B, Kostecky L, Blachly N, Yee W. Effect of a quality improvement project to use exclusive mother's own milk on rate of necrotizing enterocolitis in preterm infants. Breastfeed Med. 2015;10(7):355-61. doi: 10.1089/bfm.2015.0042

40. Landers S, Hartmann BT. Donor human milk banking and the emergence of milk sharing. Pediatr Clin North Am. 2013;60(1):247-60. doi: 10.1016/j.pcl.2012.09.009

41. Wallace CA, Holyoak L, Powell SC, Dykes FC. HACCP - The difficulty with Hazard Analysis. Food Control. 2014;35:233-40. doi: 10.1016/j. foodcont.2013.07.012

42. García-Lara NR, García-Algar O, Pallás-Alonsoa CR. Sobre bancos de leche humana y lactancia materna. An Pediatr (Barc). 2012;76(5):247-9. doi: 10.1016/j.anpedi.2011.06.001

43. Agarwal R, Green R, Agarwal N, Randhawa K. Benchmarking management practices in Austrálian public healthcare. J Health Organ Manag 2016;30(1):31-56. doi: 10.1108/JHOM-07-2013-0143

44. Wind A, van Harten WH. Benchmarking specialty hospitals, a scoping review on theory and practice. BMC Health Serv Res. $2017 ; 4 ; 17(1): 245$. doi: 10.1186/s12913-017-2154-y

45. Vignochi L, Goncalo CR, Rojas AL. How do hospital managers use performance indicators? Rev Adm Empres. 2014;54(5):496-509. doi: 10.1590/S0034-759020140504 